\title{
Social Vulnerability to Natural Hazards in Brazil
}

\author{
Beatriz Maria de Loyola Hummell ${ }^{1} \cdot$ Susan L. Cutter ${ }^{2} \cdot$ Christopher T. Emrich $^{2}$
}

Published online: 21 June 2016

(C) The Author(s) 2016. This article is published with open access at Springerlink.com

\begin{abstract}
Although social vulnerability has recently gained attention in academic studies, Brazil lacks frameworks and indicators to assess it for the entire country. Social vulnerability highlights differences in the human capacity to prepare for, respond to, and recover from disasters. It varies over space and time, and among and between social groups, largely due to differences in socioeconomic and demographic characteristics. This article provides a social vulnerability index $\left(\mathrm{SoVI}^{\circledR}\right)$ replication study for Brazil and shows how SoVI ${ }^{\circledR}$ concepts and indicators were adapted to the country. SoVI ${ }^{\circledR}$ Brazil follows the place-based framework adopted in the Social Vulnerability Index initially developed for the United States. Using a principal component analysis (PCA), 45 city-level indicators were reduced to 10 factors that explain about $67 \%$ of the variance in the data. Clearly identified spatial patterns showed a concentration of the most socially vulnerable cities in the North and Northeast regions of Brazil, as well as the social vulnerability of metropolitan areas and state capitals in the South and Southeast regions. The least vulnerable cities are mainly concentrated in the inland regions of the Southeast. Although different factors contribute to the social vulnerability in each city, the overall results confirm the social and economic disparities among Brazilian's regions and reflect a differential vulnerability to natural hazards at local to regional scales.
\end{abstract}

Susan L. Cutter

scutter@sc.edu

1 American Red Cross, Southwest Washington Chapter, Humanitarian Services, Vancouver, WA 98662, USA

2 Hazards \& Vulnerability Research Institute, Department of Geography, University of South Carolina, Columbia, SC 29208, USA
Keywords Brazil · Natural hazards $\cdot$ Social vulnerability $\cdot$ Social vulnerability index $\left(\mathrm{SoVI}^{\circledR}\right)$

\section{Introduction}

Natural hazards research has evolved from its initial emphasis on the physical processes and the geophysical aspects of disasters on society (Ismail-Zadeh et al. 2014) to a more nuanced understanding of the role of human agency in creating disaster risk (Hewitt 1983; Wisner et al. 2004; UNISDR 2015). Such an integrated approach to hazards and disasters research is now informing policy at all levels (Ismail-Zadeh and Cutter 2015). While exposure to a hazard may be the same among different social groups, the impacts are determined according to the varying capability of each group in handling the effects of hazards. Thus the study of vulnerability has become essential in understanding how distinct social groups are differently impacted by disasters (Kasperson et al. 2001; Cutter 2006).

Social vulnerability is the product of social and place inequalities (Cutter et al. 2003). Even though there are debates about the viability of measuring social vulnerability (Birkmann 2013), the social vulnerability index $\left(\mathrm{SoVI}^{\circledR}\right)$ has gained general acceptance as one of the leading tools for quantifying social vulnerability (Cutter and Morath 2013) due to its fairly robust nature and replication ability, although there is uncertainty especially among areas identified as highly vulnerable (Tate 2013). SoVI ${ }^{\circledR}$ has successfully been applied in many contexts and in many different places (De Oliveira Mendes 2009; Emrich and Cutter 2011; Holand et al. 2011; Chen et al. 2013; Guillard-Gonçalves et al. 2014; Siagan et al. 2014). 
While social vulnerability has recently gained considerable attention in academic studies, many societies still lack awareness of how social differences within their population play a role in disaster impacts. Brazil currently lacks integrated place-based assessments of disaster, risk, and vulnerability that cover the country's entire territory, as well as frameworks for evaluating vulnerability for the whole country (Hummell 2013). This article contributes to closing this gap by applying the social vulnerability index $\left(\mathrm{SoVI}^{\circledR}\right)$ in Brazil. The replication of the original SoVI ${ }^{\circledR}$ in the Brazilian context is important for two reasons. First, it provides evidence of the workability of the algorithm in the context of another country, and customizes SoVI ${ }^{\circledR}$ for an emergent industrialized Global South nation. Second, the replication study enhances the comparative assessment of vulnerability for the whole nation of Brazil and provides evidence-based understanding of regional and local differences in the capacities to prepare for, respond to, and recover from natural hazards.

Population growth and urban expansion increase exposure to hazards, and the fastest growing cities are located in developing countries (IPCC 2012; Gu et al. 2015). Although disasters affect areas equally regardless of the social conditions, the impacts vary according to the level of development and the preexisting vulnerability of residents (Kasperson et al. 2001; Birkmann 2013; World Bank 2014), often disproportionately affecting the poorest of the poor. Developing countries record greater human losses due to disasters than developed countries (IPCC 2012; UNISDR 2015).

Brazil has registered increasing trends in disaster frequency and impacts in the past decades (UFSC CEPED 2013). The accelerated growth of urban centers is historically allied with the uneven distribution of wealth among Brazil's different regions and within cities. The central and southern regions have the majority of the country's developed areas, while the northern regions have most of the country's concentrated poverty. Social disparity within cities is present throughout the country. The mixture of increasingly different socioeconomic groups in the same proximate location within the country highlights the importance of measuring social vulnerability at sub-national levels of geography. It also indicates the importance of customizing social vulnerability indices according to different scenarios and levels of development.

\section{Study Area}

The starting point for the SoVI ${ }^{\circledR}$ replication was the Brazilian state of Paraná, one of the three states in the South region. Once we successfully completed the replication at the city scale for Paraná, the study expanded to include all 5565 Brazilian cities as study units. The cities are organized in 26 states and the Federal District and distributed in five main regions (Fig. 1).

The regions' many socioeconomic, demographic, and development differences reflect directly on social vulnerability. The origin of these differences can be traced to Brazil's historic patterns of urbanization. Two time periods were important for the urban development process in Brazil. The first period in the mid-1800s included Brazil's independence in 1822, the opening of the country's markets to international commerce, the growth in coffee production, and the beginning of industrialization, all of which enabled a great economic rise. The resulting wealth brought improvements in urban areas and infrastructure, such as railways. However, these improvements were concentrated in areas of coffee production and factories, mainly the Southeast region of the country, especially in the state of São Paulo. Investment in the North and Northeast regions was much slower. The arrival of the Portuguese royal family (1808) and their followers, fleeing the French invasion of Portugal, brought institutional stability to Brazil. The bureaucracy, aristocracy, and military establishment associated with the royal family, coupled with the large number of immigrants after slavery was abolished in 1888 , brought many changes to Brazil's culture, landscape, and urban infrastructure (Santos 1996; Gomes 2007).

The second time period started around the 1930s, when political innovations (for example, change in government economic policy from export-centered to import substitution industrialization, central government intervention for coffee price supports, and promotion of economic diversification) enabled growth in the industrialization process and the internal market, providing a new economic and territorial logic (Santos 1996). The new industrialization process, rural mechanization, and population growth resulted in rural-to-urban migration, and accelerated urban growth. New production methods demanded concentrated infrastructure and a labor force close to the industrial sites that were located in a few urban centers. These factors resulted in the creation of Brazil's metropolitan areasmainly in the Center-West, Southeast, and South regionswith concentrated populations, development, and the production of wealth (Carvalho 2006).

This uneven development process was also found within cities, where differences among social groups within the same city are reflected in building patterns, infrastructure, and services. The spatial patterns in Brazilian cities are explained by the great migration from rural areas to urban centers in the country since the 1930s, due to the growing industrialization. The production sites demanded the concentration of an unskilled labor force (Bottomore 1998) in urban centers and created areas dominated by low wages and poor working conditions, and the expansion of informal work. Growing low-income populations were pushed 


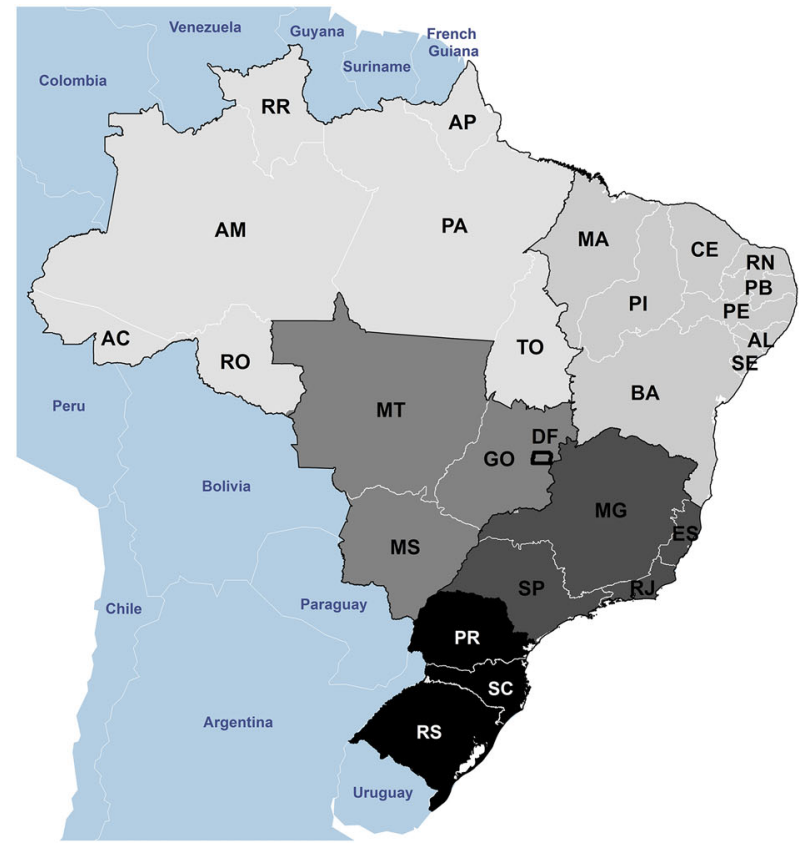

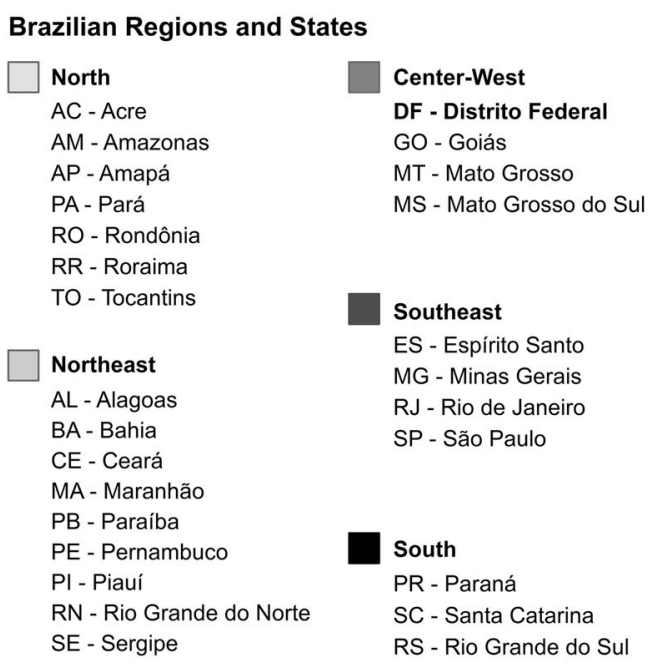

Fig. 1 The regions and states of Brazil. Source Authors

to the cities' suburbs with poor infrastructure because of the central cities' high land prices (Giddens 2000). Internal migration in the country also intensified during this period due to the prohibition of emigration to Latin America by many European countries (Juttel 2007). The migration process continues in Brazilian cities and metropolitan areas to the present day, with large poorly urbanized settlements (favelas) within cities and suburbs throughout the country. Favelas are usually located in areas unfit for development (such as slopes and floodplains) that lack infrastructure such as paved roads and access to public water and sanitation. The populations living in these areas are commonly stricken by natural hazards, especially floods and landslides.

Brazil had close to 191 million inhabitants in the 2010 census (IBGE 2010) and has now reached 204.5 million (Population Reference Bureau 2015). The population is mostly concentrated in the South, Southeast, and Northeast, especially close to coastal areas, where most of the country's largest cities are located (Fig. 2). Income distribution and households living in extreme poverty continue to reflect the historical concentration of development and wealth in the central, southeast, and southern portions of the territory.

\section{Data and Methods}

The data used for constructing the social vulnerability index for Brazil were mainly taken from the 2010 Census, provided by the Brazilian Institute of Geography and
Statistics (IBGE). We also used data from the Ministry of Social Assistance (2010) and the Ministry of Health (2011). Most data were available at country, state, or city levels. The city (defined as a politically-determined municipality) was the unit of analysis, so our analysis has a total of 5565 study units.

The social vulnerability assessment is based on the original Social Vulnerability Index $\left(\mathrm{SoVI}^{\circledR}\right)$ by Cutter et al. (2003), which included built environment variables. Because the original study was conducted for the United States, many adaptations were necessary in the application of the same methodology to Brazil. However, the main concepts were used in the search for indicators, and variables were chosen according to the data available in Brazil and their relevance to the country's situation (Table 1). Socioeconomic status, race and ethnicity, and quality of the built environment indicators required the most attention in translating the method from the U.S. to the Brazilian context.

The race and ethnicity indicators correspond to the Brazilian Census classification of Color and Race-White, Black, Brown (Pardo ${ }^{1}$ ), Yellow (Asian), and Indian. In the original $\mathrm{SoVI}^{\circledR}$, the White population indicator is not included because of its high statistical negative correlation with the minority groups. Low values on the minority groups mean higher percentages of white populations in the US context. According to the 2010 Brazil Census, $47 \%$ of the country's population are White and $43 \%$ are Brown.

\footnotetext{
${ }^{1}$ Pardo is the term used to describe individuals with multiracial background (IBGE 2010).
} 
Fig. 2 Population density, income, and households in extreme poverty in Brazil. The exchange rate used was 1 USD $=3.4739$ Brazilian Real (BRL) (Brazil Central Bank 2016. American Dollar Exchange Rate on June 7th 2016. http://www4.bcb.gov.br/ pec/taxas/batch/taxas.asp?id= txdolar (Portuguese), accessed on 7 June 2016). Data source: IBGE (2010)

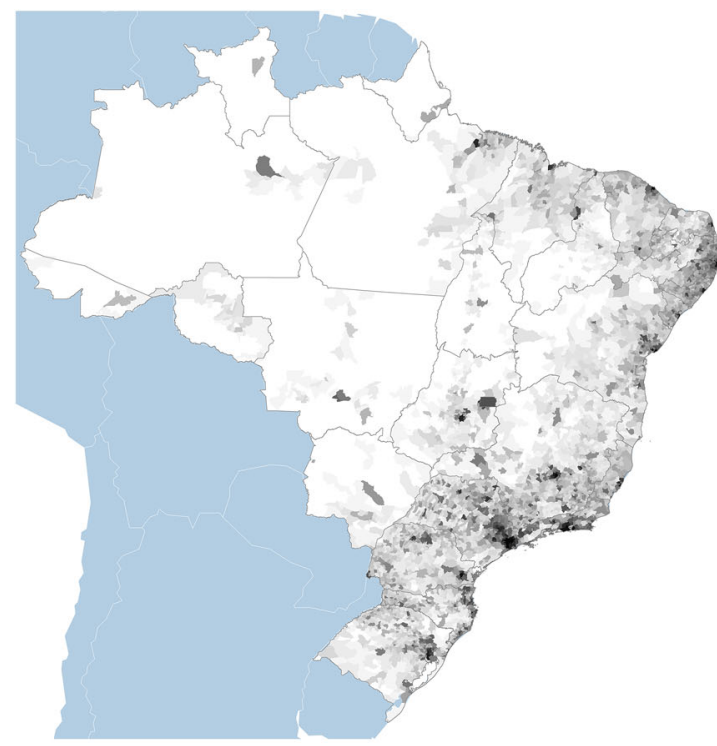

Population Density (inhabitants $/ \mathrm{Km}^{2}$ )

$0.13-3.93$

$9,069-13,024$

Data source: IBGE, 2010

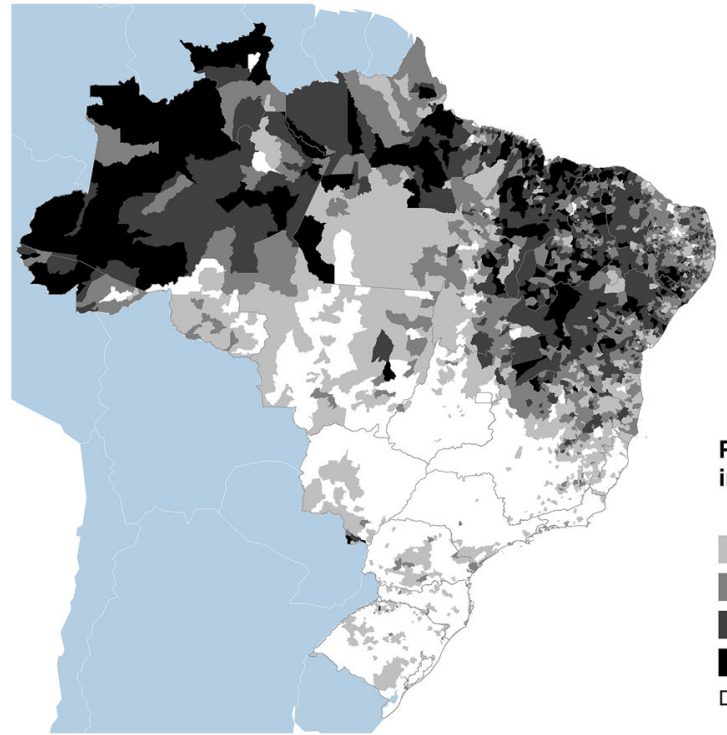

Percentage of households in extreme poverty $0.0005-0.0710$ $0.0710-0.1607$ $0.1607-0.2609$ $0.2609-0.3719$ $0.3719-0.6668$ Data source: IBGE, 2010.

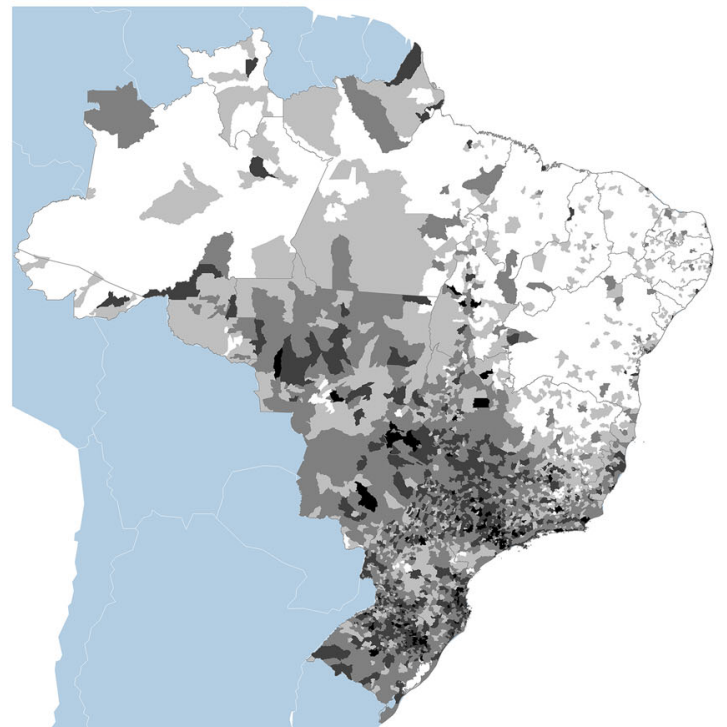

Household per capita income $(\mathbf{R} \$)$ $119-410$ $411-611$ $612-827$ $828-1167$ $1167-2303$ Data source: IBGE, 2010. Exchange rate: US\$1 $=R \$ 3,4739$ as of June $7^{\text {th }} 2016$. Source: Brazil Central Bank, 2016. 
Table 1 Variables used in the Social Vulnerability Index $\left(\operatorname{SoVI}^{\circledR}\right)$ Brazil

\begin{tabular}{|c|c|c|c|}
\hline Concept & No. & Variable name & Description \\
\hline \multirow[t]{3}{*}{ Socioeconomic status } & 1 & QEXPOV & $\begin{array}{l}\text { Percentage of population living in households earning up to } \mathrm{R} \$ 70,00 \text { per capita per } \\
\text { month (extreme poverty) }\end{array}$ \\
\hline & 2 & QMORFAM & Percentage of families living in households with more than 1 family \\
\hline & 3 & QNOPHONE & Percentage of households with no phone (cell phone or landline) \\
\hline \multirow[t]{3}{*}{ Gender } & 4 & QFEMALE & Percent females \\
\hline & 5 & QFEMLF & Percentage of employed females in the labor force \\
\hline & 6 & F_M_INC & Ratio female/male mean monthly income \\
\hline \multirow[t]{5}{*}{ Race and ethnicity } & 7 & QWHITE & Percentage of White population \\
\hline & 8 & QBLACK & Percentage of Black population \\
\hline & 9 & QASIAN & Percentage of Asian population \\
\hline & 10 & QPARDO & Percentage of Pardo population \\
\hline & 11 & QINDIAN & Percentage of Indian population \\
\hline Age & 12 & MEDAGE & Median age \\
\hline \multirow[t]{7}{*}{$\begin{array}{l}\text { Employment loss (single sector } \\
\text { reliance) }\end{array}$} & 13 & QAGRI & $\begin{array}{l}\text { Percent population employed in agriculture, fishing, forestry production, livestock, and } \\
\text { aquaculture }\end{array}$ \\
\hline & 14 & QEXTRACT & Percent population employed in extractive industry \\
\hline & 15 & QTRAN & Percent population employed in transportation \\
\hline & 16 & QACCOM & Percent population employed in accommodation activities \\
\hline & 17 & QFEED & Percent population employed in food service activities \\
\hline & 18 & QCOM & Percent population employed in commerce \\
\hline & 19 & QPUBAD & Percent population employed in public administration, defense and social security \\
\hline \multirow[t]{2}{*}{ Urban/Rural } & 20 & QURBAN & Percentage of urban population \\
\hline & 21 & POPDEN & Population density \\
\hline Renters & 22 & QRENTER & Percentage of population living in rented households \\
\hline \multirow[t]{3}{*}{ Occupation } & 23 & QLEGWO & Percentage of labor force with legal work registration \\
\hline & 24 & QNOTLEG & Percentage of labor force with no legal work registration \\
\hline & 25 & QSUBS & Percentage of subsistence workers in the labor force \\
\hline \multirow[t]{2}{*}{ Family structure } & 26 & QFHH & Percentage of female-headed households with no shared responsibility \\
\hline & 27 & PPUNIT & Average number of people per household \\
\hline \multirow[t]{3}{*}{ Education } & 28 & QILLIT & Percentage of illiterate population aged 15 and older \\
\hline & 29 & QED12LESS & Percentage of population that completed middle school or with high school incomplete \\
\hline & 30 & QCOLLEGE & Percentage of population that completed college degree \\
\hline Population change & 31 & POPCHANGE & Population change 2000-2010 \\
\hline \multirow[t]{2}{*}{ Medical services \& access } & 32 & QHHS & Percentage labor force working in human health and social work services \\
\hline & 33 & HLTHCOV & Estimated population coverage by basic health teams (2011) \\
\hline \multirow[t]{2}{*}{ Social dependency } & 34 & SSBENPC & Number of benefits granted by social security per year per capita \\
\hline & 35 & QAGEDEP & Percentage of population under age 14 and over age 60 \\
\hline \multirow[t]{2}{*}{ Special needs populations } & 36 & QSPCNEED & Percentage of population with at least one type of deficiency \\
\hline & 37 & QSPCHIGH & $\begin{array}{l}\text { Percentage of population with extremely high degree of deficiency (visually impaired, } \\
\text { hearing and motor disability) }\end{array}$ \\
\hline \multirow[t]{5}{*}{ Quality of the built environment } & 38 & QNOWATER & Percentage of households with no water infrastructure or well \\
\hline & 39 & QNOSEWER & Percentage of households with no sewer infrastructure \\
\hline & 40 & QNOGARB & Percentage of households with no garbage collection services \\
\hline & 41 & QNOELECT & Percentage of households with no electricity service \\
\hline & 42 & QLOWQUAL & Percentage of population living in households with low quality external walls \\
\hline
\end{tabular}


Table 1 continued

\begin{tabular}{llll}
\hline Concept & No. & Variable name & Description \\
\hline Migration & 43 & QBORNST & Percentage of population born in other states \\
& 44 & QFORBORN & Percentage of foreign born population \\
& 45 & QNEWRES & Percentage of residents immigrating in the past 3-5 years
\end{tabular}

Data source All from the 2010 Census (IBGE 2010), except HLTHCOV (Ministry of Health 2011) and SSBENPC (Ministry of Social Assistance 2010)

Black and Brown together make up $50.7 \%$ of the Brazilian population, up from $44.7 \%$ in 2000. This population is largely concentrated in the North and Northeast regions of the country, while the majority of the White population is concentrated in the South and Southeast regions. The average monthly income of the White and Asian populations is about twice as high as that of the Black, Brown, and Indian populations (IBGE 2011a).

The built environment indicators relate to the availability of water, sewers, electricity, and garbage collection, and the quality of the housing building materials. In many cities, portions of the population are provided with infrastructure and services, while the poorest parts of the population are not. This is most critical in favelas (or "subnormal agglomerates" according to the census definition), which account for approximately $6 \%$ of the Brazilian residences (with 11.4 million people) concentrated in 323 cities (IBGE 2011c). The 2010 Census includes considerable specificity regarding the availability of different infrastructures, so we selected indicators that presented the worst-case contexts for households. For example, the lack of water infrastructure (QNOWATER) indicator identified households that did not have running water inside homes either through city water or wells. The indicator included households that have water provided by water trucks, rivers and other water bodies, and rainwater as having no water infrastructure, and thus as highly vulnerable. In the case of natural hazards, especially droughts and floods, these households would be greatly affected. The no sewer (QNOSEWER) indicator included all households that did not have sewer or pluvial infrastructure, but did have cesspools. After a natural disaster, these households could require more time recovering, and would be at greater risk of soil and water contamination.

Indicators of health coverage and social security were not found in the 2010 Census data. The indicator for health coverage (HLTHCOV) (Ministry of Health 2011) accounts

\footnotetext{
${ }^{2}$ Subnormal agglomerates are defined as groups of at least 51 poor housing units that for the most part lack essential public services, occupy —or until recently occupied-a third-party property (public or private), and are generally arranged in a disorderly, dense way (IBGE 2011b).
}

for the number of basic health teams (family, clinic, gynecology, and pediatrics) per 3000 inhabitants in 2010 (Ministry of Health 2013). The indicator of social security benefits per capita was calculated based on the number of social security benefits granted in 2010 in each city (Ministry of Social Assistance 2010).

Initially a set of 58 variables was collected and normalized to percentage, per capita, or density functions. After a test of multicollinearity (Pearson's R) among the variables, the set was reduced to 45 indicators (Table 1). The variables were standardized according to the original methods adopted by Cutter et al. (2003). A factor analysis, using principal component analysis (PCA), was conducted using Kaiser normalization and Varimax rotation to provide the most robust set of independent factors. For interpretation purposes, the most significant indicators (with correlations over 0.5 and less than -0.5) were assumed as drivers of each component and provided the rationale for the naming conventions and corresponding cardinality $( \pm)$ according to their influence on social vulnerability. The overall influence of the factors on vulnerability was determined based on positive values that indicated higher levels of vulnerability, while negative values indicated lower levels of vulnerability. If the factor effect was ambiguous (both increased and decreased vulnerability), we assumed the absolute value. SoVI ${ }^{\circledR}$ was then calculated by the sum of the components for each city. We did not assume any weight for the different factors, meaning they have the same importance in the overall sum and the same contribution to the cities' overall vulnerability. To identify the most and least vulnerable cities, SoVI ${ }^{\circledR}$ scores were mapped based on five categories according to the standard deviation from the mean, ranging from -1.5 (low vulnerability) to +1.5 (high vulnerability).

\section{Components of the Social Vulnerability Index $\left(\right.$ SoVI $\left.{ }^{\circledR}\right)$ Brazil}

Ten factors resulting from the statistical analysis for SoVI ${ }^{\circledR}$ Brazil explain $67.0 \%$ of the variance-similar to the original SoVI ${ }^{\circledR}$ constructions for the United States. Overall 
the factors correspond to Brazil's settlement and development process. Each factor's name, cardinality, and drivers are listed in Table 2. A brief interpretation of the factors is presented below.

\subsection{Poverty}

The first factor explains $19.5 \%$ of the variance and represents poverty. The poorest and least developed populations are usually more easily devastated by natural hazards and have a harder time recovering from them. This is the factor where indicators of wealth, development, and education loaded negatively (white population, female labor force, college education) and indicators of poverty, dependency, and lack of education loaded positively (for example, Brown population, households with large numbers of people, social dependency, illegal workers). The northern regions show a concentration of areas with higher vulnerability (Fig. 3a), a function of the country's historic and enduring development process.

\subsection{Urban/Rural Development}

The second factor (Fig. 3b) identified areas of low development (agriculture workers, no phone, subsistence, lacking garbage collection and sewer infrastructure) loading negatively and indicators of urban areas (employment (transportation, commerce workers, renters, legal workers) and college education) loading positively. We took the inverse of this factor so that higher percentages of agricultural workers, and no sewer infrastructure, meant higher levels of social vulnerability. This factor explains $17.6 \%$ of the variance.

\subsection{Migration}

The third factor explains $5.4 \%$ of the variance and is driven by residents born in other states and immigration within the past 3 to 5 years. The Center-West and part of the North region show the highest vulnerability (Fig. 3c). In the past, the Southeast region used to receive the highest rate of immigrants. The expansion of agricultural land in the Center-West and North regions that has attracted more people, and the lower rates of economic growth in the Southeast that is reflected in lower job offer rates, precipitated this change in internal migration patterns. Many internal migrants are returning populations that left in the past and are now coming back to their original cities or states. In the case of a disaster, migrants, especially those who have recently moved to a new city, would have less experience with the conditions in their new living area and lack knowledge about the types of natural hazards likely to
Table 2 Components, major drivers, and direction of influence of social vulnerability $( \pm)$ according to the Social Vulnerability Index (SoVI ${ }^{\circledR}$ ) Brazil

\begin{tabular}{|c|c|c|}
\hline Component name & Cardinality & $\begin{array}{l}\text { Drivers (factor } \\
\text { correlation) }^{\mathrm{a}}\end{array}$ \\
\hline 1. Poverty & + & $\begin{array}{l}\text { QPARDO }(0.891) \\
\text { QWHITE }(0.883) \\
\text { MEDAGE }(-0.850) \\
\text { QAGEDEP }(0.808) \\
\text { QILLIT }(0.767) \\
\text { QFEMLF }(-0.765) \\
\text { QEXPOV }(0.761) \\
\text { PPUNIT }(0.727) \\
\text { QNOPHONE }(0.659) \\
\text { QNOTLEG }(0.616) \\
\text { QED12LESS } \\
(-0.528) \\
\text { QCOLLEGE } \\
(-0.526) \\
\text { QNOWATER } \\
(0.522)\end{array}$ \\
\hline 2. Urban/Rural Development & - & $\begin{array}{l}\text { QAGRI }(-0.889) \\
\text { QURBAN }(0.886) \\
\text { QNOGARB } \\
(-0.764) \\
\text { QCOM }(0.753) \\
\text { QRENTER (0.745) } \\
\text { LEGWO (0.715) } \\
\text { QNOSEWER } \\
(-0.656) \\
\text { QSUBS }(-0.654) \\
\text { QCOLLEGE }(0.579) \\
\text { QHHS }(0.574) \\
\text { QTRAN }(0.561) \\
\text { QFEED }(0.530) \\
\text { QNOPHONE } \\
(-0.516)\end{array}$ \\
\hline 3. Migration & + & $\begin{array}{l}\text { QBORNST (0.796) } \\
\text { QNEWRES }(0.758)\end{array}$ \\
\hline 4. Special needs population & + & $\begin{array}{l}\text { QSPCNEED }(0.702) \\
\text { QFEMALE }(0.501)\end{array}$ \\
\hline $\begin{array}{l}\text { 5. Race (Indian) and poor } \\
\text { infrastructure }\end{array}$ & + & $\begin{array}{l}\text { QINDIAN }(0.741) \\
\text { QNOELECT }(0.556) \\
\text { QLOWQUAL } \\
(0.512)\end{array}$ \\
\hline 6. Lack of public employment & + & QPUBAD (-0.776) \\
\hline 7. Tourism-based economy & + & $\begin{array}{l}\text { QACCOM }(0.770) \\
\text { QFEED }(0.511)\end{array}$ \\
\hline 8. Racial diversity & $\|$ & QBLACK (0.685) \\
\hline 9. Population density & + & POPDEN $(-0.652)$ \\
\hline 10. Extractive industry & + & QEXTRACT (0.824) \\
\hline
\end{tabular}

$\overline{{ }^{a}}$ Only those drivers with correlations of 0.500 or greater are listed in the table 
happen there. This could result in more difficulty reacting to and recovering from disasters.

\subsection{Special Needs Population}

The fourth factor is driven by population with special needs and females and explains $4.9 \%$ of the variance. The Northeast region shows the highest vulnerability, the North region has the lowest overall vulnerability (Fig. 3d). Special needs populations can be greatly affected by disasters, since they require special attention or infrastructure for mobility and rescuing purposes. Females can have a harder time when facing disasters, especially in the recovery period, due to dependency on certain employment sectors (service industry such as hotel maids), lower wages, and family care responsibilities.

\subsection{Race (Indian) and Poor Infrastructure}

The fifth factor is driven by Indian population, households with no electricity, and houses built with poor construction materials. The factor explains $4.2 \%$ of the variance. Indian population is usually related to lower levels of development and poor infrastructure, as well as more fragile types of housing construction. These populations have a harder time preparing for and recovering from disasters. The areas close to the Amazon have higher social vulnerability and reflect the large concentrations of Indian populations in those areas (Fig. 3e).

\subsection{Lack of Public Employment}

The sixth factor explains $3.9 \%$ of the variance and is driven by the level of public sector employment (for example, the lack of population employed in public administration, defense, and social security). A minor driver is the lack of health coverage. Public employment is usually related to secure jobs, which would indicate an asset especially in the recovery process from a natural hazard event. Health coverage indicates populations with better health indices and a larger availability of health assistance after a natural disaster. The Center-West region (including the Federal District) and part of the North region presented the cities with lower social vulnerability scores (Fig. 3f).

\subsection{Tourism-Based Economy}

The seventh factor explains $3.2 \%$ of the variance and is driven by employment in accommodation and food service activities. Regions that are heavily dependent on tourismrelated activities have a harder time recovering from a natural hazard event that could diminish the tourist resources and infrastructure in the area for a long time.
Border and coastal cities that are usually driven towards tourist activities are the most vulnerable (Fig. 3g).

\subsection{Racial Diversity}

Black populations drive this factor that explains $3.1 \%$ of the variance. Pardo and Asian populations loaded positively and White and Indian populations loaded negatively, the latter with less strength. This factor highlights the racial and ethnic diversity and racial mixing in the country. Bigger cities and more developed areas usually have more diverse racial concentrations where disparities in income and education contribute to increased social vulnerability. Smaller communities and those with similar racial backgrounds generally have better community organization traditions and enhanced social networks that lead to lower levels of vulnerability. Because the different indicators of race are ambiguous and have different signs (positive and negative), we adopted the absolute value for this factor (Fig. 3h).

\subsection{Population Density}

The ninth factor is driven by population density (inhabitants per $\mathrm{km}^{2}$ ) and explains $2.8 \%$ of the variance. A large population in the same area suggests not only that more people would be affected by a disaster, but also that they would have more difficulty in an eventual evacuation or rescue situation, making them more vulnerable to the natural hazard. State capitals and larger cities, usually with regional economic importance, and a few places in northeastern areas illustrate higher vulnerability (Fig. 3i). The Center-West region has many agricultural areas and lower social vulnerability cities.

\subsection{Extractive Industry}

The tenth factor is driven by extractive industry employment and explains $2.6 \%$ of the variance. Populations that rely on extractive industries can face a long period of unemployment after disasters. If an entire region or city depends on extraction industry activities, major economic problems could occur in the aftermath of a disaster. The central portion of the country concentrates extractive industry activities that make these areas more socially vulnerable than other areas in the country (Fig. 3j).

\section{The Geography of Social Vulnerability in Brazil}

The majority of Brazilian cities present moderate levels of social vulnerability (Fig. 4) with values ranging from +27.67 (high social vulnerability) to -9.27 (low social vulnerability). The most vulnerable cities are located in the North and Northeast regions (red areas). These areas are 

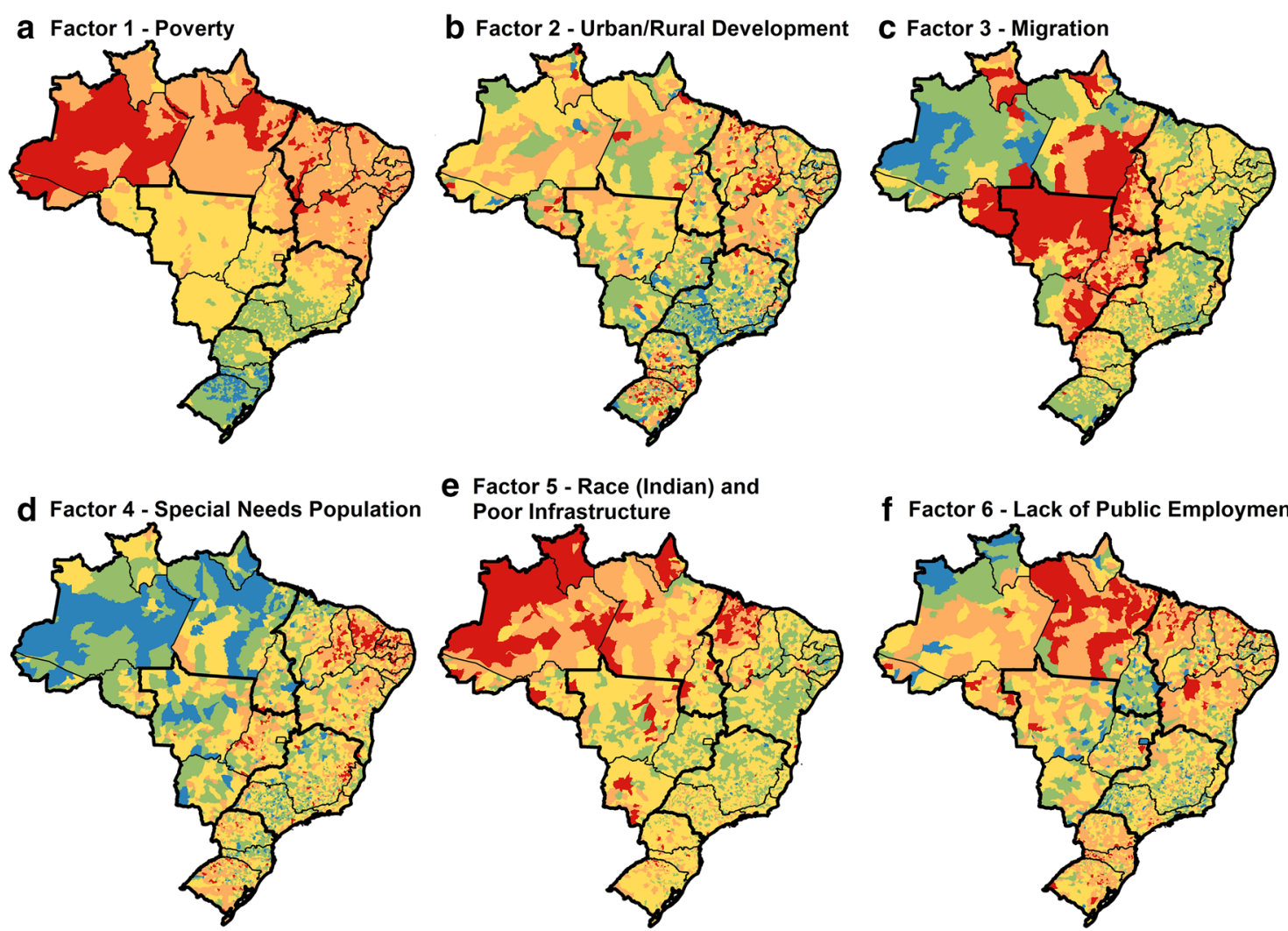

f Factor 6 - Lack of Public Employment
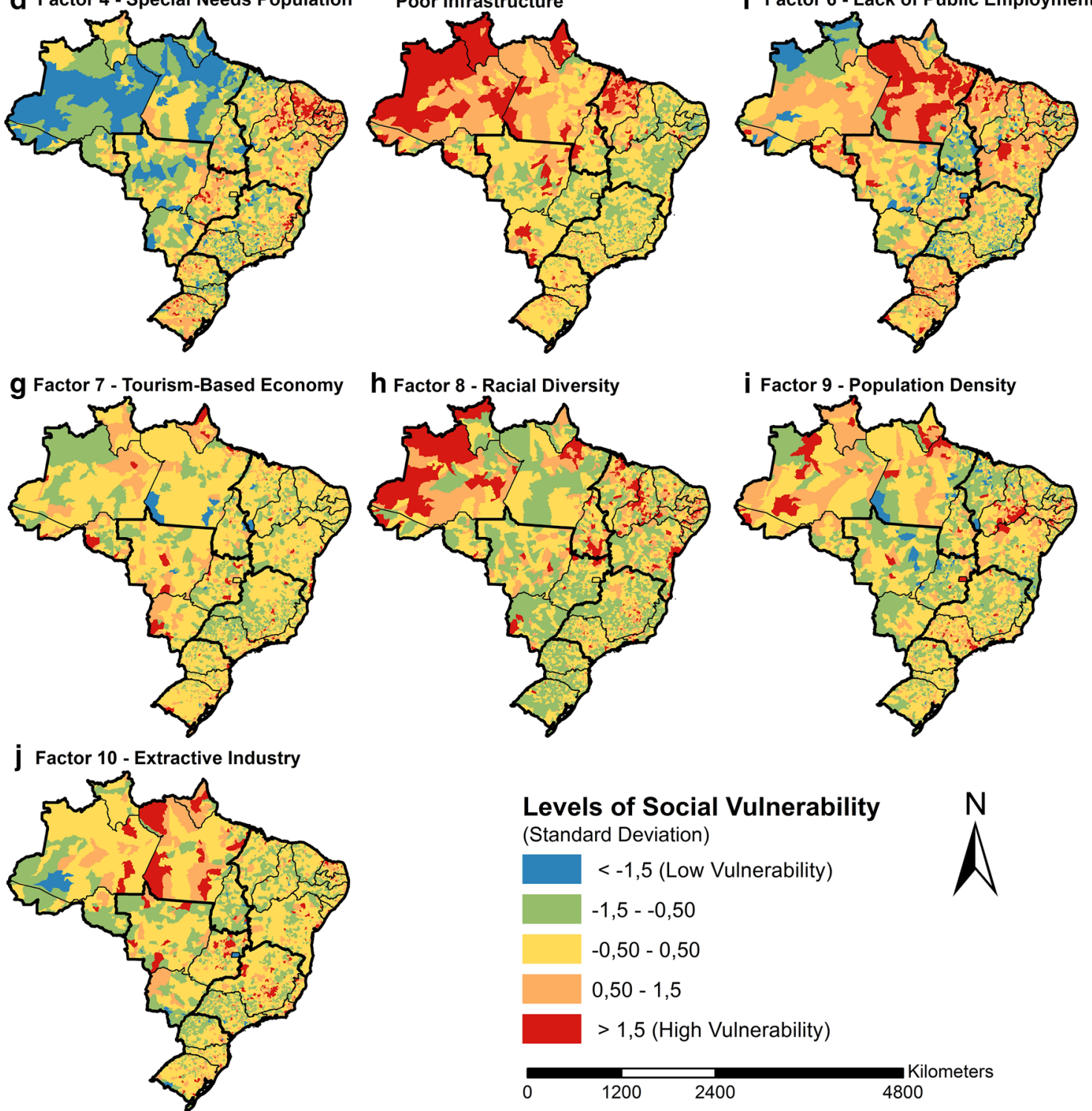

Fig. 3 Geographic distribution of individual Social Vulnerability Index (SoVI $\left.{ }^{\circledR}\right)$ factors and levels of social vulnerability in Brazilian cities. Source Authors 
characterized by high poverty and constitute the least developed areas in the country. The Amazon region and the dry areas in the Northeast lack infrastructure and contain many conservation areas (such as the Amazon forest). This partially explains the lack of development and the poverty in the region. These areas received fewer investments in the past. Climate issues in the Northeast (with annual droughts) also account for the low development and higher social vulnerability. The North region has the highest concentration of Indian populations in the country, and Black and Pardo inhabitants account for the majority of the Northeast's population. The Northeast region also has cities with high levels of special needs populations, because of poor health care, aging population, and high concentration of poverty. Cities in metropolitan regions and intensely populated state capitals like São Paulo and Rio de Janeiro also have high levels of social vulnerability (Fig. 4). High population density, migration, Black and Indian populations, and in Rio de Janeiro a tourism-based economy explain the high social vulnerability levels in these cities.

Among the state capitals, the most vulnerable are Fortaleza, São Paulo, and Recife. These cities have high population densities and significant percentages of Black and Pardo populations. In general, these cities are known for high levels of urban violence and disparity among social groups. The least vulnerable state capitals are all in the Center-West region: Brasília, Campo Grande-MS, and Cuiabá-MT. As the national capital, Brasília has a concentration of high-income jobs in public employment. In contrast, many surrounding cities concentrate poor labor forces that support the national capital and show higher levels of social vulnerability. Cuiabá has lower population density and lower poverty rates in comparison to other state capitals, as well as a small concentration of special needs population, due to lower levels of poverty and availability of good-quality infrastructure and healthcare. Campo Grande also has low population density and poverty rates, concentrates White and Indian populations, and has a low dependency on extractive industry activities.

Most cities with low social vulnerability are concentrated in the inland region of the Southeast (blue areas). These areas present high levels of development with higher income levels and good-quality infrastructure. Some of these cities are engaged in profitable agricultural activities, such as soy and sugar cane plantations, and have many higher-education institutions. There is also a concentration of cities with relatively low social vulnerability in the South region (green areas). Here higher levels of development and profitable agricultural activities, as a result of the comparatively good national investments in infrastructure, combine to produce the lower social vulnerability. Brazil's largest cities (São Paulo and Rio de Janeiro) are located in the Southeast and concentrate diversified economic activities and higher levels of development and infrastructure. The three state capitals in the South region (Curitiba-PR, Florianopolis-SC, and Porto Alegre-RS) indicated low levels of extreme poverty among state capitals, and are generally known for good infrastructure and good quality of life. As is the case with the majority of Brazilian cities, social inequalities in the same city are pronounced, however, though cities in the South and Southeast regions offer an overall better quality of life and development in comparison to other areas in the country.

The three cities with the highest social vulnerability are Uiramutā-RR, Pedra Branca do Amapari-AP, and Chuí-RS. In Uiramutā the factors that most increase vulnerability are race (Indian) and poor infrastructure. Other factors that contribute to high social vulnerability are racial diversity, population density, extractive industry, and the lack of urban/rural development. In Pedra Branca do Amapari, on the borders of Venezuela and Guyana, the clustering of Indian reserves is a primary factor that influences the level of social vulnerability, along with extractive industry and migration. In Chuí, social vulnerability is a product of the tourism-based economy and race (Indian). The three least vulnerable cities in Brazil are Lavínia-SP, Serra da Saudade-MG, and Pracinha-SP. The factors that most contribute to decreased social vulnerability in these cities are low levels of special needs populations, low concentration of poverty and Indians, good infrastructure and high rates of public employment.

\section{Conclusion}

This article provides an assessment of social vulnerability in Brazil by applying the SoVI ${ }^{\circledR}$ method (with customized variables) at the city level. The historic, economic, and social characteristics of the country become evident when assessing social vulnerability. Significant social differences exist among the country's regions, especially those that contain highdensity urban areas and racially diverse populations.

The results of the study show that, in general, regions in the north contain the most socially vulnerable cities and the South and Southeast regions have cities with lower levels of social vulnerability. This pattern consistently agrees with the levels of development distributed among the country's regions and the historic patterns of development. The northern regions received less investments than the southern regions, especially the Southeast. Other factors, such as the concentration of European immigrants working in agricultural activities since the late 1800s and the development of industry in the mid-1900s also added to development and improved quality of life in southern regions. Although factors contribute to social vulnerability differently in each city, the overall results confirm that the social and economic 


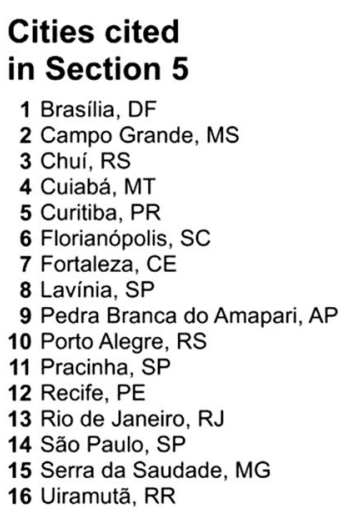

SoVI Brazil (Standard Deviation)

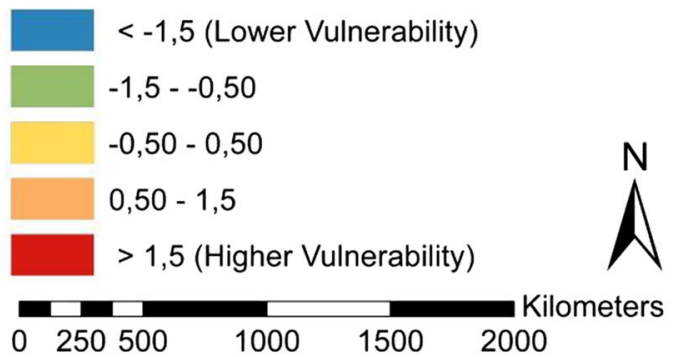

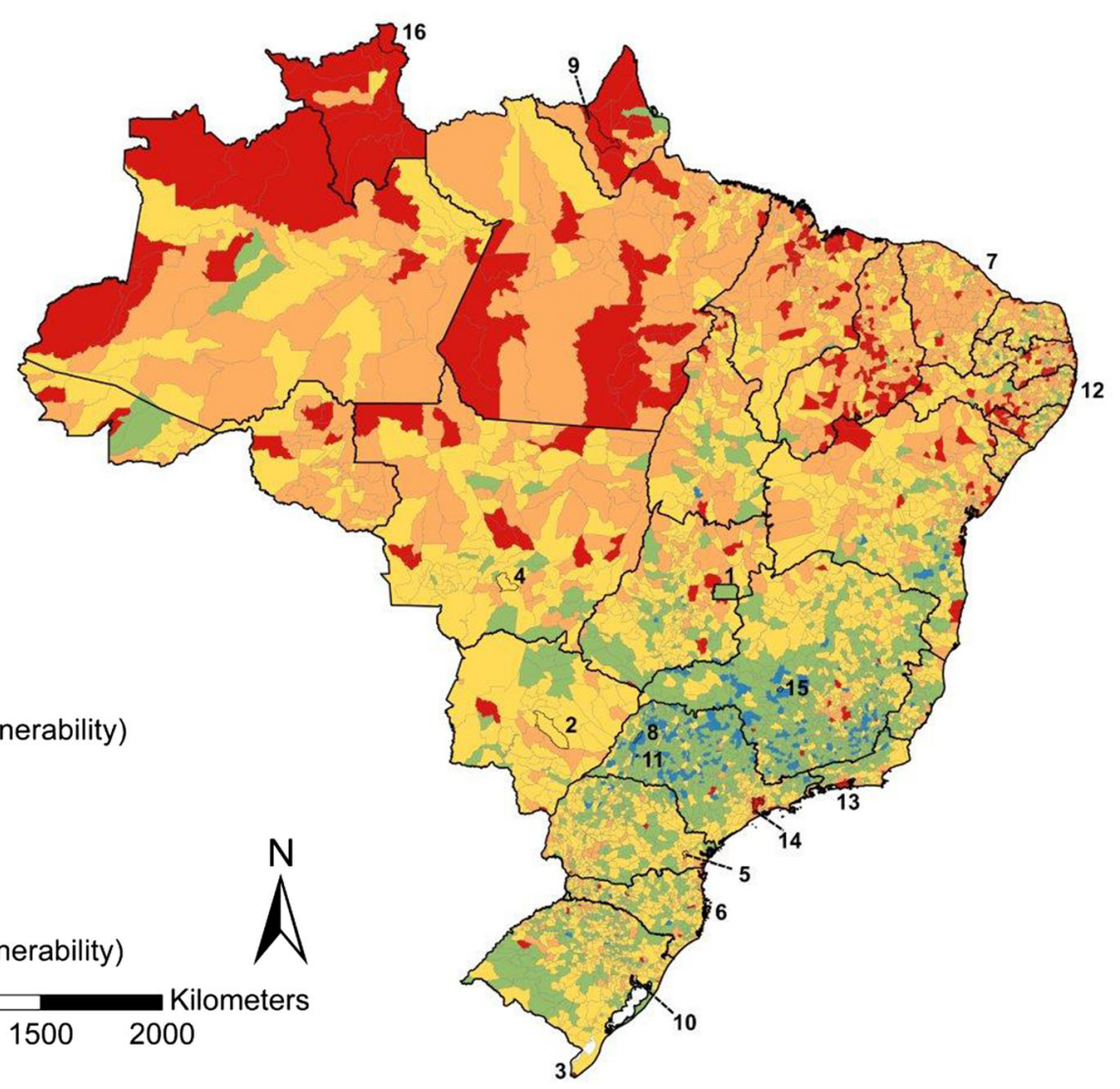

Fig. 4 Comparative social vulnerability of Brazilian cities based on the Social Vulnerability Index (SoVI ${ }^{\circledR}$ )

disparities among Brazil's different regions are indicative of the population's social vulnerability to natural hazards.

This study demonstrates that it is possible to make a place-based integrated vulnerability assessment for an entire country. Such an analysis can be used as a reference for policymakers in taking appropriate decisions on disaster risk reduction measures at the city level. Although the social differences within Brazilian cities are clear, the citylevel assessment presents multiple factors, such as poverty, migration, special needs populations, that interact together to identify the geography of social vulnerability-identifying which areas are the most or least vulnerable and the factors contributing to this vulnerability. Although many of these factors have been discussed individually by other disciplines, the integrated nature of the assessment that focuses on the social vulnerability to natural hazards in Brazil contributes a new approach.

This study also demonstrates that SoVI ${ }^{\circledR}$ can be used in countries with different historic backgrounds, social contexts, and information sources. It adds to the body of knowledge on the comparative assessment of social vulnerability among different countries. The next step is to compare SoVI ${ }^{\circledR}$ with a disaster indicator in order to identify the most affected populations to particular threat sources. The results of comparing social and physical aspects should enable policymakers to make appropriate decisions based on what aspects contribute to increasing the vulnerability of the most affected populations to natural hazards.

Acknowledgments The authors would like to express their great appreciation to Dan Morath, Ronnie Schumann, Kevin Ash, Robert Gottlieb, Gregg Bowser, Juliana Lam, and other colleagues in the Hazards \& Vulnerability Research Institute, University of South Carolina, for contributing valuable advice and integrating the discussions during the development of this study. We also thank the editors for their editorial review of the article.

Open Access This article is distributed under the terms of the Creative Commons Attribution 4.0 International License (http://creative commons.org/licenses/by/4.0/), which permits unrestricted use, distribution, and reproduction in any medium, provided you give appropriate credit to the original author(s) and the source, provide a link to the Creative Commons license, and indicate if changes were made.

\section{References}

Birkmann, J. (ed.). 2013. Measuring vulnerability to natural hazards: Towards disaster resilient societies. Bonn: United Nations University Press.

Bottomore, T. 1998. A dictionary of marxista thought (Dicionário do pensamento marxista). Rio de Janeiro: J. Zahar (in Portuguese).

Carvalho, I.M. 2006. Globalization, metropolis and social crisis in Brazil (Globalização, Metrópole e Crise Social no Brasil). EURE (Santiago) 32(95): 5-20 (in Portuguese). 
Chen, W., S.L. Cutter, C.T. Emrich, and P. Shi. 2013. Measuring social vulnerability to natural hazards in the Yangtze River Delta region, China. International Journal of Disaster Risk Science 4(4): $169-181$.

Cutter, S.L. 2006. Hazards, vulnerability and environmental justice. London and Sterling, VA: Earthscan.

Cutter, S.L., B.J. Boruff, and W.L. Shirley. 2003. Social vulnerability to environmental hazards. Social Science Quarterly 84(2): 242-261.

Cutter, S.L., and D.P. Morath. 2013. The evolution of the Social Vulnerability Index. In Measuring vulnerability to natural hazards, 2nd edn., ed. J. Birkmann, 304-321. Bonn: United Nations University Press.

De Oliveira Mendes, J.M. 2009. Social vulnerability indexes as planning tools: Beyond the preparedness paradigm. Journal of Risk Research 12(1): 43-58.

Emrich, C.T., and S.L. Cutter. 2011. Social vulnerability to climatesensitive hazards in the southern United States. Weather, Climate, and Society 3(3): 193-208.

Giddens, A. 2000. Sociology (Sociologia), 2nd edn. Lisboa: Fundação Calouste Gulbenkian (in Portuguese).

Gomes, L. 2007. 1808: How a mad queen, a scared prince and a corrupt court deceived Napoleon and changed the history of Portugal and Brazil (1808: Como Uma rainha louca, um príncipe medroso e uma corte corrupta enganaram Napoleão e mudaram a história de Portugal e do Brasil), 2nd edn. São Paulo: Editora Planeta do Brasil (in Portuguese).

Gu, D., P. Gerland, F. Pelletier, and B. Cohen. 2015. Risks of exposure and vulnerability to natural disasters at the city level: A global overview. Population Division Technical Paper No. 2015/2. New York: United Nations Department of Economic and Social Affairs. http://esa.un.org/unpd/wup/Publications/Files/WUP2014-Techni calPaper-NaturalDisaster.pdf. Accessed 7 Mar 2016.

Guillard-Gonçalves, C., S.L. Cutter, C.T. Emrich, and J.L. Zêzere. 2014. Application of Social Vulnerability Index (SoVI) and delineation of natural risk zones in Greater Lisbon, Portugal. Journal of Risk Research 18(5): 651-674.

Hewitt, K. 1983. Interpretations of calamity from the viewpoint of human ecology. Boston: Allen \& Unwin.

Holand, I.S., P. Lujala, and J.K. Rød. 2011. Social vulnerability assessment for Norway: A quantitative approach. Norwegian Journal of Geography 65(1): 1-17.

Hummell, B.M.L. 2013. Hazards, social vulnerability and resilience in Brazil: An assessment of data availability and related research. Source 17: 44-63.

IBGE (Brazilian Institute of Geography and Statistics). 2011a. Press room November 19, 2011. http://saladeimprensa.ibge.gov.br/en/ noticias?view $=$ noticia\&id $=1 \&$ busca $=1 \&$ idnoticia $=2019$. Accessed 16 Apr 2013 and 7 Mar 2016.

IBGE (Brazilian Institute of Geography and Statistics). 2011b. Press room December 15, 2011. http://saladeimprensa.ibge.gov.br/en/ noticias?view=noticia\&id=1\&busca $=1 \&$ idnoticia=2051. Accessed 16 Apr 2013 and 7 Mar 2016.

IBGE (Brazilian Institute of Geography and Statistics). 2011c. Press room December 21, 2011. http://saladeimprensa.ibge.gov.br/en/ noticias?view $=$ noticia\&id $=1$ \&idnoticia $=2057 \&$ busca $=1 \& \mathrm{t}=$ censo2010-11-4-milhoes-brasileiros-6-0-vivem-aglomerados-subnor mais. Accessed 16 Apr 2013 and 7 Mar 2016.

IBGE (Brazilian Institute of Geography and Statistics). 2010. 2010 Census (Censo 2010). http://www.ibge.gov.br/home/estatistica/ populacao/censo2010/default.shtm. Accessed 10 Jan 2013.

IPCC (Intergovernmental Panel on Climate Change). 2012. Summary for policymakers. In: Managing the risks of extreme events and disasters to advance climate change adaptation. A special report of Working Groups I and II of the Intergovernmental Panel on Climate Change, ed. C.B. Field, V. Barros, T.F. Stocker, D. Qin,
D.J. Dokken, K.L. Ebi, M.D. Mastrandrea, K.J. Mach, G.-K. Plattner, S.K. Allen, M. Tignor, and P.M. Midgley, 1-19. Cambridge and New York: Cambridge University Press.

Ismail-Zadeh, A., and S.L. Cutter (eds.). 2015. Disaster risks research and assessment to promote risk reduction and management. Paris: ICSU-ISSC AD-HOC Group on Disaster Risk Assessment. http://www.icsu.org/science-for-policy/disaster-risk/docu ments/DRRsynthesisPaper_2015.pdf. Accessed 7 Mar 2016.

Ismail-Zadeh, A., J.U. Fucugauchi, A. Kijko, K. Takeuchi, and I. Zaliapin (eds.). 2014. Extreme natural hazards, disaster risks and societal implications. Cambridge: Cambridge University Press.

Juttel, L.P. 2007. North and Center-West, new migration hubs (Norte e Centro-Oeste, novos pólos de migração). Ciência e Cultura 59(4): 10-11 (in Portuguese).

Kasperson, R.E, J.X. Kasperson, and K. Dow. 2001. Vulnerability, equity, and global environmental change. In Global environmental risk, ed. R.E. Kasperson, and J.X. Kasperson, 247-272. London: United Nations University Press.

Ministry of Health. 2011. Health system performance index 2011 (Índice de Desempenho do Sistema Único de Saúde - IDSUS 2011). http://portal.saude.gov.br/portal/saude/area.cfm?id_area= 1080. Accessed 16 Apr 2013 and 7 Mar 2016 (in Portuguese).

Ministry of Health. 2013. Technical indicator files of the health system performance index 2013 (Fichas Tecnicas dos Indicarores do Índice de Desempenho do Sistema Único de Saúde IDSUS 2013). http://portal.saude.gov.br/portal/arquivos/pdf/ IDSUS_Fichas_Tecnicas_Indicadores.pdf. Accessed 16 Apr 2013 and 7 Mar 2016 (in Portuguese).

Ministry of Social Assistance. 2010. Statistical yearbook of social assistance 2010 (Anuário Estatístico da Previdência Social AEPS 2010). http://www.previdencia.gov.br/dados-abertos/aeps2010-anuario-estatistico-da-previdencia-social-2010. Accessed 16 Apr 2013 and 7 Mar 2016 (in Portuguese).

Population Reference Bureau. 2015. 2015 world population data sheet. http://www.prb.org/wpds/2015. Accessed 6 Jun 2016.

Santos, M. 1996. Brazilian urbanization (A urbanização brasileira), 3rd edn. São Paulo: Hucitec (in Portuguese).

Siagan, T., P. Purhadi, S. Suhartono, and H. Ritonga. 2014. Social vulnerability to natural hazards in Indonesia: Driving factors and policy implications. Natural Hazards 70(2): 1603-1617.

Tate, E. 2013. Uncertainty analysis for a social vulnerability index. Annals of the Association of American Geographers 103(3): 526-543.

UFSC CEPED (Universidade Federal de Santa Catarina - Centro Universitário de Estudos e Pesquisas sobre Desastres). 2013. Brazilian atlas of natural disasters 1991 to 2012: Volume Brazil second edition revised and expanded (Atlas brasileiro de desastres naturais 1991 a 2012: Volume Brasil $2 a$ edição revisada e ampliada). Florianópolis: CEPED UFSC. http://www. ceped.ufsc.br/biblioteca/projetos/encerrados/atlas-brasileiro-dedesastres-naturais. Accessed 4 Feb 2013 and 7 Mar 2016 (in Portuguese).

UNISDR (United Nations International Strategy for Disaster Reduction). 2015. Global assessment report on disaster risk reduction (GAR15). Making development sustainable: The future of disaster risk management. Geneva: United Nations Office for Disaster Risk Reduction.

Wisner, B., P. Blaikie, T. Cannon, and I. Davis. 2004. At risk: Natural hazards, people's vulnerability, and disasters, 2nd edn. London and New York: Routledge.

World Bank. 2014. Risk and opportunity: Managing risk for development. World development report 2014. Washington DC: World Bank. http://siteresources.worldbank.org/EXTNWDR2013/Resources/82 58024-1352909193861/8936935-1356011448215/8986901-13800 46989056/WDR-2014_Complete_Report.pdf. Accessed 7 Mar 2014. 